\title{
Children with type 1 diabetes mellitus: the experience of disease*
}

\author{
A criança com diabetes Mellitus Tipo 1: a vivência do adoecimento \\ El niño con diabetes mellitus tipo 1: la experiencia de enfermar
}

How to cite this article:

Aguiar GB, Machado MED, Silva LF, Aguiar RCB, Christoffel MM. Children with type 1 diabetes mellitus: the experience of disease. Rev Esc Enferm USP. 2021;55:e03725. doi: https://doi.org/10.1590/S1980-220X2020011803725

\section{Gabriela Bolzan Aguiar ${ }^{1}$ \\ Maria Estela Diniz Machado ${ }^{1}$ \\ Liliane Faria da Silva ${ }^{1}$ \\ Rosane Cordeiro Burla de Aguiar ${ }^{1}$ \\ Marialda Moreira Christoffel ${ }^{2}$}

* Extracted from the undergraduate thesis: "A criança com diabetes mellitus tipo 1: vivência e enfrentamento”, Escola de Enfermagem Aurora de Afonso Costa,

Universidade Federal Fluminense, 2018.

1 Universidade Federal Fluminense,

Escola de Enfermagem Aurora de

Afonso Costa, Niterói, RJ, Brazil.

2 Universidade Federal do Rio de Janeiro, Escola de Enfermagem Anna Nery, Rio de Janeiro, RJ, Brazil.

\begin{abstract}
Objective: To identify the main challenges faced by children with type 1 diabetes mellitus and describe their coping strategies. Method: Qualitative study conducted with a semi-structured interview with children aged 8 to 11 with type 1 diabetes mellitus diagnosis who received care in the outpatient clinic of a university hospital in the state of Rio de Janeiro, Brazil. The results have been analyzed and categorized as per thematic analysis. Results: Five children have participated. The reports have emerged from the systematization of the qualitative data, in a process of apprehending meaning from statements of children and adolescents, which led to the category "Living with diabetes", including two subcategories: "Challenges to disease coping" and "Family participation and support in the disease process". Conclusion: The process of disease coping is observed to occur differently for each child. However, family participation and support, as well as communication with health professionals, are fundamental in this process.
\end{abstract}

\section{DESCRIPTORS}

Child; Diabetes Mellitus, Type 1; Adaptation, Psychological; Pediatric Nursing; Family; Chronic Disease. 


\section{INTRODUCTION}

Type 1 diabetes mellitus (T1DM) is a non-communicable chronic disease characterized by the destruction of pancreatic beta cells, which are responsible for insulin production. It is one of the leading metabolic and endocrine disorders among children and adolescents ${ }^{(1)}$. In the 2019 world ranking, Brazil was in the third place, with 51,500 children and adolescents ( $0-14$ years old) with T1DM and an estimate of 7,300 new cases per year ${ }^{(2)}$.

The interactions of children with T1DM are related to both physiological and emotional impairment. Throughout treatment these children experience stressful situations which affect family and social interactions, considering that the therapy for controlling this disease entails activity limitations, a specific diet, submission to painful procedures, body changes, and repeated hospitalizations. When faced with these demands, children may have difficulties accepting their condition, which provokes resentment due to a selfperception of being different from their peers ${ }^{(3)}$.

The challenges of living with T1DM are many and health professionals must understand these, as well as coping strategies, to help children and their families in the best conduction of treatment and in their adaptation to a new way of living. Children are the best sources of information on their own experiences and feelings. They may express their thoughts in diverse manners and to this end health professionals must enter their universe and let them express their experiences ${ }^{(3-4)}$.

Children must be given a voice for their singularities to be respected, given that most childcare studies approach this theme from the perspective of families or health professionals ${ }^{(4)}$. Listening to children with diabetes, in addition to valuing their experience, provides thus support for clinical care of this population ${ }^{(5)}$.

The importance of this study is therefore justified; its objectives were to identify the main challenges faced by children with type 1 diabetes mellitus and to describe their coping strategies to better adapt to this disease.

\section{METHOD}

\section{Design OF STUDY}

This is a qualitative study ${ }^{(6)}$ conducted in the specialized outpatient clinic of a university hospital in the state of Rio de Janeiro, Brazil.

\section{Population}

The participants amounted to five children who were under outpatient follow-up and met the following inclusion criteria: school age, literate, diagnosed with T1DM for at least a year, and accepting study participation. Excluded children were those with some mental disorder which precluded the conduction of an interview or who were not present in the outpatient consultations during the data collection phase. Upon data collection, there were six children receiving care and only one refused study participation.

\section{Data collection}

Data collection was conducted from January to February 2018. The children were invited to participate in the study while waiting for a follow-up consultation in the outpatient clinic of the endocrinology service. The semi-structured interviews were recorded and took place in a reserved and private room available at the time. The interviews lasted a mean of 40 minutes. The following trigger question was employed: "tell me: how is it like for you to live with type 1 diabetes?" The interviews were conducted with the presence of the children's guardians. After they were finished, the audios were transcribed to provide an analytical construction of the data and an understanding of the experience of children faced with the discovery of this disease and the changes they went through, as well as the perception and feelings which the experience involves.

\section{DatA TREATMENT AND ANALYSIS}

The data analysis was conducted following the Thematic analysis technique ${ }^{(6)}$. This study followed the three steps for the operationalization of qualitative data: Pre-analysis, exploration of the material, and treatment of the results to produce senses and meanings from interference and interpretation. The core meanings were identified and grouped for categorization considering the central and relevant ideas of the children's statements.

\section{ETHICAL ASPECTS}

The study has abided by the directives and criteria established in Resolution 466/12, by the National Health Council, and was approved by the Research Ethics Committee of this study's hospital in Opinion n. 2.436.143 in December 2017. Participant anonymity was guaranteed through identification with the letter $\mathrm{C}$ (for child) followed by Arabic numerals according to the sequence of the interviews $(1,2,3, \ldots)$. The Informed Consent Form was provided in two copies to each child's guardian and only after it was read and clarified was it signed by those who accepted participation. The children signed the assent form and were assured the freedom of spontaneous participation and the right to give up at any moment during the research.

\section{RESULTS}

The study participants totaled five children: three females and two males, aged 8 to 11, who were between the fourth and seventh grades of primary school. Duration of disease ranged from two to six years within the group.

From the children's statements, a single category has emerged: "Living with diabetes", comprising two subcategories: "Challenges to disease coping" and "Family participation and support in the disease process".

\section{LIVING WITH DIABETES}

This category refers to the daily life of children with T1DM, their feelings, the difficulties of accepting the disease, and their routine at school, at home, and with their friends. 


\section{Challenges to disease coping}

While experiencing T1DM, children undergo many phases as a consequence of their diagnosis and their lives start to change remarkably. These changes lead to a deep transformation of their world and require that they live under certain limits, situations, and new routines. They must face many challenges each day: everything they are no longer able to do, difficulties with insulin application, and barriers and limitations regarding nutrition, mainly on sweet food, as observed in the following utterances:

Well, it's hard (...). Everyone is like: oh, you've had this since you were little, so you're going to have more control than the others. No, that's not how it works. It's hard because I've done lots of silly things I wasn't supposed to do (C1).

It's just that, when sugar is high, I get upset when I see people having sweets $(\mathrm{C} 2)$.

Not having sweets. This is hard for me... and taking insulin every day, too (C3).

(...) I'd see people having sweets and I'd want it too, but I know can't have it now, but I really liked it. I used to eat a lot. Now I can't eat like that (C5).

One of the participating children has emphasized the difficulty of accepting disease as permanent. While seeming to accept the disease, she has hope that it will be temporary, a cure will be found one day, and she will no longer be required to submit to these situations:

(...) well, I know I have it, but there's also, like: I hope one day they'll find a cure and I won't have to lead this thing of... hey, it would be great not to be diabetic (C1).

With time children acquire self-knowledge and start to learn and recognize their body signs regarding the disease. They start to understand dizziness, tiredness, polydipsia (desire of drinking water), or frequent urination, as emphasized in the following statements:

(...) then I felt bad, I didn't know how to speak, I couldn't speak, because sometimes things like these happen, you lose your voice, you go blind, you can't speak (C1).

Sometimes my body feels bad. When diabetes strikes, I get tired, my back hurts. When it's high, I drink water all the time, then I go to the toilet all the time (C3).

Sometimes it's upsetting, because when I have no sugar, I get pretty bad, I feel tired, can't feel my legs, I get dizzy (C4).

However, when children start to recognize signs and symptoms and to understand their meanings, they also notice that they cannot maintain their routine, play with the same intensity, or perform physical exercise as before discovering T1DM:

Oh, biking. I used to bike a lot, used to run. Now I can't, I get tired, I get tired faster. Sometimes when I'm biking my leg feels weak, then I stop. (C4).
Like, there's Physical Education at school, then I do it, but not too much, because I get really tired (...) Walking alone as well, so I don't walk alone (C5).

Another challenge faced by children is related to capillary glycemia monitoring, frequency of insulin administration, marks of its application on the body, and the need for performing these procedures many times a day:

Pricking me (...) it feels very bad and my finger hurts after that (...) my belly (...) gets all spotty (...) because it's so many times $(\mathrm{C} 4)$.

(...) my finger hurts [during capillary glycemia monitoring]... And also my belly [during insulin application]. Well, I know what I have to do it, so I do it (C5).

The feeling of resentment brought by this experience is directly related to the process of disease acceptance. The interviews show their frustration, non-resignation, and irritation, mainly with insulin, treatment, and diet:

(...) there's that thing of not wanting to apply insulin, I don't want to do that. I don't want to prick my finger, it gets hurt, all pricked. This is something I sometimes just don't want. There are moments I think I don't have diabetes, because my results are $\operatorname{good}(\mathrm{C} 1)$.

I don't like getting insulin. Sometimes I tell mom I don't want [to take insulin].(...) It really burts (C2).

(...) and I have to get my finger pricked all the time (...) and, well, it hurts. I don't like that as well (C3).

It's horrible. I didn't know what this was and had to stop with many things I like eating. Then she [the physician] advised against everything I liked and I got really mad (C4).

I didn't know what it was, and after she [the physician] explained, I couldn't believe I'd not have sweets anymore and get pricked (...) I thought it would pass, but this is for good (...) I got mad (C5).

This feeling is also followed by fear and anxiety in face of prejudice, which may lead to isolation. This may happen mainly at school and among groups of friends, in addition to the label which is imposed on children with T1DM when they are discriminated against. These are also reasons not to tell everyone about their disease:

No, they [friends] don't know (C2).

I have two best friends. I told them. But I don't usually tell, I don't. So, there are people who know I have this, but I try not to tell anyone $(\mathrm{C} 4)$.

However, the biggest challenge to be faced daily by the interviewed children in this environment is related to how T1DM manifests and their health needs, which may often lead to exposure, as is noticeable in the following statements:

And then at school if I felt bad, I'd leave the room; sometimes I'd be one hour outside, because my glycemia was high or low because of my treatment $(\mathrm{C} 1)$. 
(...) the teacher lets me drink water. The teacher doesn't let other boys drink water much. But she'll let just me. They asked her and then she told them I have diabetes (C3).

(...) I know because I get like this [body feels bad] and then I leave the room and eat something. The teachers also know and they let me do it (C4).

In addition to this, children with T1DM are noticed to require constant follow-up and care by the health team, which encompasses physicians, nurses, nutritionists, psychologists, and occupational therapists. However, in the children's experience, physicians, nurses, and nutritionists are perceived as more present, as shown in the utterances below:

I try to eat properly, to eat what the nutritionist tells me to (C1).

The doctor told me. Then a woman came [the nurse] and took me to this room to explain that part about pricking the finger (C3).

Then they take us to that room and tell us how to prick and where (...) well, they explained (C5).

Health professional performance is noticed to constitute yet another challenge. The professionals' approach to various situations in providing care to children with T1DM is illustrated below:

(...) the nurses and physicians [of the emergency] were going to cut my insulin, they wanted to start giving me other insulins, wanted to change my treatment. They never asked anything (C1).

(...) the doctor also told me [during diagnosis], but I couldn't understand (...). Why I had to stop eating all that (...) what that was, I didn't know (C4).

(...) took me to the hospital (...) and then I was there for a very long time (...) they pricked me to draw blood and I was left taking medicine through the vein (...) then the doctor said I had diabetes. Just like that (C5).

However, this study has also found a statement by a child who has received different orientation, with the use of other technologies, including educational material, to support disease coping.

In the insulin [an external institution] I got a book (...) they give us a book about a little frog who's diabetic. (...) In the hospital... I got notbing (C2) [This child received the material in a consultation in another institution after diagnosis].

\section{FAMILY PARTICIPATION AND SUPPORT IN THE DISEASE PROCESS}

In this subcategory, the family was also observed to undergo a period of adjustment for disease acceptance, using strategies to live with and take care of their child, often searching for professional help:

I went to therapy, my mother and me. This was last year, on Wednesdays. I don't go anymore. There we talked and told everything, you know? (C3).

Also, relatives, such as parents and siblings, are a necessary part of care since they act as facilitators for adapting their children and siblings to the disease. The children consider the family as a support, as observed below:

(...) at school now I was down and I told mom: "don't leave" (...) Then I asked her to stay there with me, because I didn't want to be there alone. Then she stayed with me (C1).

They [family] take care of me and stay with me (C2).

(...) having people with me (...). But well, my parents and my brother are there (...) it already helps (C5).

The importance of family is also observed in the hospital environment in situations of urgency or hospitalization. In the utterances below, the presence of the family in these situations is observed to be of utmost importance, since children are supported by their relatives, considering their family a safe place:

I was once taken to the hospital and if my mom weren't there, I'd be screwed (C1).

(...) it was my last day there [in the hospital] (...) all my family was there to visit me $(\mathrm{C} 2)$.

As children adapt to their new needs, learning to live with no sweet food, opting for healthier nutrition, taking care of their bodies, the family starts to encourage and influence these processes. As a form of support, they often change their own nutrition habits and routines:

(...) my mom does my nails (...) because they told me to take care of my feet. Then I wash and dry my toes a lot, but she's the one who does my nails, she cuts them to avoid inflammation (C5).

My mom and my sister don't have sweets. They eat what I eat. This is helpful, because then I don't feel like having sweets so much. It's helpful then (C4).

\section{DISCUSSION}

According to the statements by the children participating in this study, the challenges of living with T1DM include the need for nutritional changes, among which restrictions to sweet foods have been emphasized. This data is consistent with another study, in which nutritional restrictions due to therapeutic demands and the difficulties of not being able to eat like friends who do not have T1DM were found to be factors which impact the daily lives of individuals with T1DM. The mentioned factors include limitations to the ingestion of sweet foods among friends in moments of leisure and at school ${ }^{(7)}$.

Other authors reinforce this idea and argue that nutrition is one of the main allies of treatment and is thus considered also as the major villain and one of the main challenges, since there is a difficulty in accepting nutritional restrictions, mainly regarding sweet foods ${ }^{(8)}$.

Offering and selling healthy food in school canteens in Brazil, as proposed in the interministerial ordinance of the Ministry of Health and the Ministry of Education, n. 1.010, dated May 8, 2006 ${ }^{(9)}$, would reduce the discomfort experienced by children whose diets have restrictions and would stimulate the adoption of healthier food for all children ${ }^{(3)}$. 
Also, the understanding that this disease is incurable and that it will be present in their daily lives, regardless of their desires, is a constant challenge. Even when children have been diagnosed many years ago, their adaptive process may last an indeterminate amount of time. There is thus no specific amount of time for the child to undergo these challenges and adapt to the new reality. This happens continuous and singularly, in their own time. As children adapt, they start to recognize their body language. Living with the disease and its imposed needs, children can recognize the symptoms of hypoglycemia or hyperglycemia and are able to act to minimize such symptoms. The knowledge and skills to manage the disease bring a positive outlook on the life of these children, who are in a period of growth and development ${ }^{(5)}$.

Commonly, these symptoms manifest when they practice physical activities and, consequently, some of them feel unable to exercise. However, regular physical activity is recommended for children with T1DM, since they present a higher risk for developing microvascular (diabetic retinopathy, nephropathy, neuropathy) and cardiovascular diseases, which are causes of early death if not properly treated. In general, adherence to a diet through an individualized nutrition plan, glycemic control, and practice of physical exercises are considered essential conditions for preventing disease complications and early death ${ }^{(10)}$.

Regarding treatment and self-care, some responses include the child's refusal to accept the therapy or of admitting their sickness. This denial may intensify during social interaction. When children are at school, they broaden their social circle. Considered one of the main scenarios for this social circle, the school is an environment in which children with T1DM must deal with their disease in front of other significant people, such as their classmates, teachers, and other people who are part of this context ${ }^{(11)}$.

This environment may represent an important social support in the experience of children with chronic illness, essentially in diabetes control, in the identification and correction of glycemic changes, as well as in the prevention of hypoglycemia; the school may thus also impact the child's life negatively, when classmates and other friends do not consider that the child has T1DM or when they do not collaborate with the diet, since children with T1DM have nutritional restrictions which may occasionally lead to embarrassment and social exclusion ${ }^{(11)}$.

Concerning the school environment, teachers have an important and direct role related to children with T1DM. Teachers must receive orientation about the disease, its treatment, and the restrictions that children experience, not only to inform students with diabetes, but also their social circle, since, in addition to physical health, children must have psychological health, given that childhood is a period of intense knowledge construction, growth, and human development ${ }^{(12)}$. In addition, it is essential that health teams approach schools. The integration between school and health professional contributes to the development of coping strategies against chronic illness and the challenges childcare entails ${ }^{(11)}$.
Concerning health professionals, children with T1DM are known to have a need for monitoring, support, and continuous follow-up by a multiprofessional team, since, when children are followed systematically, chronic complications of T1DM can be prevented, avoiding negative consequences for these individuals' quality of life and physical and emotional aspects, which may preclude appropriate treatment adherence ${ }^{(3)}$.

However, when the goal is to develop self-care, increase the child's knowledge, and value their experiences and social network support, multiprofessional work does not suffice; the work of a specialized interdisciplinary team is required to potentialize the control of T1DM based on a close interaction between child, family, and other members of the health team ${ }^{(11)}$. For an appropriate management of this disease, it is crucial to observe children in their many phases of growth and development, focusing on their individuality, their environment, beliefs, fears, and family relations, conducting them to a healthy life based on their potentialities and not only biomedical issues ${ }^{(3)}$.

The importance of family participation in facilitating children's coping in their experience with T1DM was also another result from this study. Children start to demand specific care and their families are eventually integrated into a new reality. Patients with T1DM who have appropriate family support have a higher adherence to self-care orientation. Family management of the situation and their knowledge of this pathology influence its acceptance or denial by the child and understanding their limitations may also help them not to resent the disease ${ }^{(13)}$. In this context, the importance of the support provided by the health team when orienting the child and its family are highlighted.

When children and their relatives understand the disease well, they create mechanisms of adaptation to T1DM. When they understand the reality in which they are inserted and have a better comprehension of the disease, individuals start to cope with it in a different manner, acquiring new nutritional and life habits, marked by the beginning of a new routine. Treatment is emphasized to be more efficient when there is adherence to behavioral changes and higher ability in daily care, such as monitoring glycemia and administering insulin ${ }^{(14-15)}$.

The hospital environment is not different. In it, the presence of a relative during care or hospitalization, guaranteed by the Child and Adolescent Statute (Estatuto da Criança e do Adolescente - ECA) ${ }^{(16)}$, contributes to the promotion and maintenance of the inter-relation between the child and its family, so as to neutralize effects from separation, collaborate in integral childcare, and improve their adaptation to the hospital context. Also, the permanence of the accompanying relative during child hospitalization is of importance, since it favors the establishment of a pleasant mood and contributes to patient care. In this case, the presence of relatives favors sharing care responsibility between the team and the family in a collaborative way which facilitates the children's adherence to treatment and painful procedures ${ }^{(17)}$, such as those needed for monitoring glycemia and the application 
of insulin. Also, it provides a space for training children and their families for home care.

Relatives must thus play a part in child treatment decisions, since this is an internal process of the family, which is the core of the children's support in daily life. Strengthening this bond through participation of the whole family enables reduction of tensions and a higher organization of the support system, bringing a positive contribution to the care of children with chronic disease ${ }^{(11)}$.

Considering that care of children with T1DM is not restricted to the disease, also encompassing the environment, an outlook towards all these components is required from health professionals. Support by the health team regarding these issues is usually inefficient, increasing difficulties in disease coping.

Nurses must also be attentive to identify an overload of the main caregiver. There must be an action plan including orientation and educational actions that provide for the modification of factors which may affect the caregivers' physical, psychological, and social health, so that they may continue to play their roles, guaranteeing thus the quality of childcare. In this context, nurses are crucial in detecting evidence that indicates possible changes in the quality of care performed by the caregiver and interfering with nursing care directed at promoting physical, psychic, and emotional well-being. Also, when necessary and available, they should help the family in the process of choosing other members to take direct responsibility in childcare or to share other home chores ${ }^{(18)}$.

It is thus relevant to evaluate their previous knowledge and to discuss the disease with children and their families, demystifying prejudice and orienting for the best manner of caring and living with T1DM. The use of creative strategies in the communication between professionals and children facilitates expressing feelings and experiences with important meanings for their clinical care ${ }^{(5)}$.

Concerning orientation, the nurse must act as a facilitator, analyzing the most appropriate manner of working with children and their relatives, sharing relevant and accurate information. Promoting health education is an extremely important duty of the nursing professional and an essential task in controlling T1DM. However, nurses, during their professional practice both in hospitals and outpatient wards, are observed to have difficulties in approaching children so that they and their families may understand, decide, and act for their health conditions, adhering to the therapeutic project. In this context, professionals must understand each subject's reality, outlook, and expectations, since this is the only way the needs of clients can be prioritized and therapeutic demands can be followed ${ }^{(5)}$.

In this perspective, when dealing with diabetic children, nurses may use educational tools to support and teach them essential care for disease control and improvement of their well-being. According to the authors, ludic stimulus is a satisfactory option for treating children with diabetes, since approaching the issue of family care in a ludic manner facilitates their process of understanding and promotes more interaction with their peers and relatives, considered as a source of energy and force ${ }^{(5)}$.

One possible strategy is a diabetes education program involving not only the child, but also the organization and qualification of the nurse and the team aiming at improving care provided to these children. To this end, the use of simple language, games, paintings, cartoons, movies, and texts may be inserted into these programs, since these recreational strategies are valid to promote the increase of expression of the children's feelings, contributing to their education, adherence to treatment, self-esteem, and others ${ }^{(19)}$.

Similarly, a study which aimed at analyzing the application of dynamics performed for the sensibilization of children for their own care by means of their experiences has observed that the approach of the child by the health team, through creative activities which provide pleasure, has promoted relaxation moments; also, it has facilitated reflection and understanding of health conditions and the use of insulin therapy, promoting socialization of their experiences. In face of this, when using educational and creative activities with children and their families, nurses are understood to stimulate and encourage the children's feeling of safety and, with this, their coping with illness and its treatment, mitigating trauma and damages ${ }^{(5)}$.

The reduced number of children due to a coincidence between the data collection period and school break is considered a study limitation. Therefore, this study may not reflect the situation of other population groups.

\section{CONCLUSION}

The process of disease coping is unique to each child. However, in this study, the feelings of fear, insecurity, resentment, denial, frustration, and anxiety were common when discovering and living with T1DM. These feelings must be valued by the health team.

In this study, it was possible to observe frailties related to the practice of the health professionals. Care of children and their families was observed to be more directed at disease control and less at psychological and social expectations, needs, and repercussions. To this end, both child and family must be heard to jointly create a support network to help elaborate coping strategies against the intense and constant daily challenges. The necessary interdisciplinary practice between the diverse health subjects must also be considered, as this may enable integral and humanized care to children and their families.

One emphasizes the importance of conducting educational practices with children and their families, mediated by recreational resources and simple language as a strategy to broaden their knowledge of T1DM, the treatment, and its limitations and to promote self-care and increase coping possibilities. 


\section{RESUMO}

Objetivo: Identificar os principais desafios vivenciados pela criança com diabetes mellitus tipo 1 e descrever as estratégias de enfrentamento que utilizam para se adaptarem. Método: Estudo de abordagem qualitativa, realizado por meio de entrevista semiestruturada com crianças de 8 a 11 anos com diagnóstico de diabetes mellitus tipo 1 atendidas em ambulatório de um hospital universitário no Estado do Rio de Janeiro. Os resultados foram analisados e categorizados segundo análise temática. Resultados: Participaram cinco crianças. Os relatos emergiram da sistematização dos dados qualitativos, em um processo de apreensão de significado dos depoimentos das crianças e adolescentes, que derivou na categoria "Viver com diabetes", com duas subcategorias: "Desafios no enfrentamento do adoecimento" e "Participação e apoio da família no processo do adoecimento". Conclusão: Constata-se que o processo de enfrentamento do adoecimento ocorre de forma singular para cada criança. No entanto, a participação e o apoio da família, assim como a comunicação dos profissionais de saúde, são fundamentais nesse processo.

\section{DESCRITORES}

Criança; Diabetes Mellitus Tipo 1; Adaptação Psicológica; Enfermagem Pediátrica; Família; Doença Crônica.

\section{RESUMEN}

Objetivo: Identificar los principales desafíos para los niños con diabetes mellitus tipo 1 y describir las estrategias de afrontamiento que utilizan para adaptarse. Método: Estudio cualitativo, realizado a través de entrevistas semiestructuradas con niños de 8 a 11 años diagnosticados con diabetes mellitus tipo 1 y atendidos en el ambulatorio de un hospital universitario del estado de Rio de Janeiro, en Brasil. Los resultados se analizaron y clasificaron según el análisis temático. Resultados: Participaron cinco niños. Los relatos surgieron de la sistematización de los datos cualitativos, en un proceso de aprehensión del significado de los testimonios de niños y adolescentes, que derivó en la categoría "Vivir con diabetes", con dos subcategorías: "Desafíos en el afrontamiento de la enfermedad" y "Participación y apoyo de la familia en el proceso de la enfermedad". Conclusión: Se constata que el proceso de afrontamiento de la enfermedad ocurre singularmente con cada niño. Sin embargo, la participación y el apoyo de la familia, así como la comunicación de los profesionales sanitarios, son esenciales en este proceso.

\section{DESCRIPTORES}

Niño; Diabetes Mellitus Tipo 1; Adaptación Psicológica; Enfermería Pediátrica; Familía; Enfermedad Crónica.

\section{REFERENCES}

1. Merino MFG, Oliveira RR, Silva PLAR, Carvalho MDB, Pelloso SM, Higarashi IH. Hospitalization and mortality by diabetes mellitus in children: analysis of temporal series. Rev Bras Enferm. 2019;72 Suppl 3:147-53. doi: http://dx.doi.org/10.1590/0034-7167-2018-0299

2. International Diabetes Federation. IDF Diabetes Atlas [internet]. Brussels: IDF; 2019. [cited 2020 June 29]. Available from: https://www. diabetesatlas.org

3. Silva MEA, Moura FM, Albuquerque TM, Reichert APS, Collet N. Network and social support in children with chronic diseases: understanding the child's perception. Texto Contexto Enferm. 2017;26(1):1-10. doi: https://doi.org/10.1590/0104-07072017006980015

4. Santos PM, Silva LF, Depianti JRB, Cursino EG, Ribeiro CA. Nursing care through the perception of hospitalized children. Rev Bras Enferm. 2016;69(4):646-53. doi: https://doi.org/10.1590/0034-7167.2016690405i

5. Queiroz MVO, Brito LMMC, Pennafort VPS, Bezerra FSM. Sensitizing children with diabetes to self-care: contributions to educational practice. Esc Anna Nery. 2016;20(2):337-43. doi: https://doi.org/10.5935/1414-8145.20160046

6. Minayo MCS. O desafio do conhecimento: pesquisa qualitativa em saúde. São Paulo: Hucitec; 2014.

7. Cordeiro TSR, Rebouças TS. Desenvolvimento e validação de tecnologia educativa para adolescentes com diabetes mellitus tipo 1. In: Siebra e Silva AV, Mattos SM, Moreira TMM, Chaves EMC, Gomes ILV, editoras. Saúde infantil e hebiátrica: ludicidade, tecnologias e desafios. Curitiba: CRV; 2019. p. 61-72.

8. Bertin RL, Elizio NPS, Moraes RNT, Medeiros CO, Fiori LS, Ulbrich AZ. Perceptions of the daily food for children and adolescents with type 1 diabetes mellitus. Rev Contexto Saúde. 2016;16(30):100-9. doi: https://doi.org/10.21527/2176-7114.2016.30.100-109.

9. Brasil. Ministério da Saúde. Portaria Interministerial n. 1.010, de 8 de maio de 2006. Institui as diretrizes para a Promoção da Alimentação Saudável nas Escolas de educação infantil, fundamental e nível médio das redes públicas e privadas, em âmbito nacional [Internet]. Brasília; 2006 [citado 2019 jun. 2]. Disponível em: http://bvsms.saude.gov.br/bvs/saudelegis/gm/2006/pri1010_08_05_2006.html

10. Andrade CS, Ribeiro GS, Santos CAST, Neves RCS, Moreira Junior E. Factors associated with high levels of glycated haemoglobin in patients with type 1 diabetes: a multicenter study in Brazil. BMJ Open. 2017;7(12). doi: 10.1136/ bmjopen-2017-018094

11. Pennafort VPS, Queiroz MVO, Nascimento LC, Guedes MVC. Network and social support in family care of children with diabetes. Rev Bras Enferm. 2016;69:856-63. doi: http://dx.doi.org/10.1590/0034-7167-2015-0085

12. Vargas DM, Barbaresco AC, Steiner O, Silva CRLD. A psychoanalytic approch at children and adolescents with diabetes Mellitus type 1 and its family. Rev Psicol Saúde. 2020;12:87-100. doi: http://dx.doi.org/10.20435/pssa.v12i1.858.

13. Gomes GC, Moreira MAJ, Silva CD, Mota MS, Nobre CMG, Rodrigues EF. Family experiences in the diagnosis of diabetes mellitus in children/adolescents. J Nurs Health [Internet]. 2019 [cited 2019 June 2];9(1):e199108. Available from: https://periodicos.ufpel.edu.br/ ojs2/index.php/enfermagem/article/view/13393/9961

14. Pimentel RRS, Targa T, Scardoelli MGC. From diagnosis to the unknown: perceptions of parents of children and adolescents with diabetes mellitus. Rev Enferm UFPE. 2017;11(3):1118-26. doi: 10.5205/reuol.10544-93905-1-RV.1103201701

15. Tonetto IFA, Baptista MHB, Gomides DS, Pace AE. Quality of life of people with diabetes mellitus. Rev Esc Enferm. USP. 2019;53:e03424. doi: https://doi.org/10.1590/s1980220x2018002803424.

16. Brasil. Lei n. 8069, de 13 de julho de 1990. Dispõe sobre o Estatuto da Criança e do Adolescente. Brasília; 1990.

17. Azevedo AVS, Lançoni JAC, Crepaldi MA. Nursing team, family and hospitalized child interaction: an integrative review. Ciênc Saúde Coletiva. 2017;22(11):365-66. doi: https://doi.org/10.1590/1413-812320172211.26362015 
18. Oliveira RA, Moura TM, Perrelli JG, Lopes MV, Mangueira SO. La tensión generada en el rol del cuidador principal frente al cuidado de niños con cáncer. Rev Cubana Enferm [Internet]. 2015 [citado 2019 Jun. 4]; 31(2). Disponíble en: http://revenfermeria.sld.cu/index.php/ enf/article/view/331.

19. Gonzaga P, Resende J, Passos V, Simões P. A influência da ludicidade para a aprendizagem de crianças em regime de internação hospitalar. REVASF [Internet]. 2016 [citado 2019 jun. 4];6(11):125-45. Disponível em: http://periodicos2.univasf.edu.br/index.php/revasf/ article/view/850/640 